Leszek Szewczyk*

Katowice

\title{
Wychowanie do przebaczenia w homiliach
}

Nadszedł znowu czas dla Kościoła, aby przyjąć na siebie radosne głoszenie przebaczenia [...]. Przebaczenie to siła, która przywraca do nowego życia i dodaje odwagi, aby patrzeć w przyszłość z nadzieją.

Franciszek, Misericordiae vultus

Przytoczone powyżej słowa pochodzą z bulli papieża Franciszka $M i-$ sericordiae vultus, zapowiadającej Nadzwyczajny Rok Święty Miłosierdzia (8.12.2015-20.11.2016). Papież dostrzega, że doświadczenie przebaczenia staje się obecnie coraz rzadsze, a niekiedy zupełnie zanika, co sprawia, że wielu współczesnych porusza się drogą bezpłodną i sterylną, jakby żyli w jakimś miejscu pustynnym, odosobnionym. Dlatego Papież prosi biskupów o ,zaproszenie i o przyjęcie tych misjonarzy, aby byli przede wszystkim przekonującymi kaznodziejami miłosierdzia. Niech zostaną zorganizowane w diecezjach «misje ludowe», tak aby misjonarze ci stali się zwiastunami radości i przebaczenia"'. Sam Franciszek staje się kaznodzieją miłosierdzia,

* Ks. dr hab. Leszek Szewczyk jest adiunktem w Katedrze Teologii Pastoralnej, Liturgiki, Homiletyki i Katechetyki Wydziału Teologicznego Uniwersytetu Śląskiego w Katowicach. Adres: Wydział Teologiczny UŚ, ul. Jordana 18, 40-043 Katowice; e-mail: leszek.szewczyk@ interia.pl.

${ }^{1}$ Franciszek, Bulla ustanawiająca nadzwyczajny Jubileusz Miłosierdzia Misericordiae vultus (11.04.2015). 
kiedy podczas modlitwy Anioł Pański w święto św. Szczepana, 26 grudnia 2015 roku, głosi:

Rzeczywiście prawdziwym świadkiem jest ten, kto zachowuje się tak jak Jezus: ten kto się modli, miłuje, kto daje, ale przede wszystkim ten, kto przebacza, ponieważ przebaczenie, jak sama nazwa wskazuje, jest najwznioślejszym wyrazem daru [...]. Pamiętajmy o tym, będzie to dla nas dobre: jeżeli chcemy postępować $\mathrm{w}$ wierze, przede wszystkim musimy otrzymać przebaczenie Boga; spotkać Ojca, który jest gotowy przebaczać wszystko i zawsze, i który właśnie przebaczając, uzdrawia serce i ożywia miłość. Musimy niestrudzenie prosić o Boże przebaczenie, ponieważ tylko kiedy doświadczymy przebaczenia, uczymy się przebaczać 2 .

Jednym $z$ podstawowych kryteriów autentyczności bycia chrześcijaninem jest umiejętność przebaczania. To, co specyfikuje chrześcijaństwo od innych religii, to ciągłe wzywanie do miłości nieprzyjaciół, z której wypływa konieczność wybaczania nawet największych przewinień. Pełna postawa chrześcijańska zakłada umiejętność przebaczania ${ }^{3}$. Do takiej postawy trzeba ciągle wychowywać. Jedną z misji Kościoła jest wychowywanie swoich członków. Kościół ma prawo i obowiązek wychowania, bowiem została mu zlecona „przez Boga misja niesienia ludziom pomocy, aby mogli osiągnąć pełnię życia chrześcijańskiego" (Kodeks prawa kanonicznego (dalej: KPK), kan. $794 \S 1$ ). Prawdziwe wychowanie powinno obejmować pełną formację człowieka i odnosić się do ostatecznego celu życia człowieka, jak i dobra wspólnego społeczności. Prawo do wychowania chrześcijańskiego mają wszyscy chrześcijanie, ponieważ nazywają się dziećmi Bożymi i nimi są (KPK, kan. 795) $)^{4}$. Podstawowe zadania wychowawcze Kościoła związane są z realizacją jego funkcji zbawczych: głoszenia słowa Bożego, oddawania czci Bogu i realizowania miłości bliźniego, opierając się na zdrowej miłości samego siebie. „Głównym poruczeniem pedagogicznym wspólnoty Chry-

2 Franciszek, „O przebaczaniu: codziennie mamy do tego okazję”, http://www.opoka. org.pl/aktualnosci/news.php?id=58404\&s=opoka (dostęp: 28.12.2015).

3 Janusz Kręcidło, „Jakiego przebaczenia uczy nas Jezus?”, Ateneum Kapłańskie 156, 1 (2011): 25.

${ }^{4}$ Sobór Watykański II, Deklaracja o wychowaniu chrześcijańskim Gravissimum educationis, nr 1, w: Sobór Watykański II, Konstytucje, dekrety, deklaracje (Poznań: Pallottinum, 1967). Zob. Marek Zaborowski, „Zadania nauczycielskie Kościoła w Polsce wobec współczesnych wyzwań rodziny", Pedagogika Katolicka 8 (2011): 92. 
stusowej jest głoszenie wszystkim ludziom drogi zbawienia i dawanie świadectwa poprzez ukazywanie wierzącym życia Chrystusa"5.

Jednym z najważniejszych środków wychowawczych, zwłaszcza w zakresie wychowania religijnego, które są w dyspozycji Kościoła, jest przepowiadanie homilijne. Jego szczególne znaczenie wynika z integralnego związku ze sprawowaną liturgią, której jest częścią. Homilii przypada tu szczególna rola w realizowanej przez Kościół misji wychowawczej ${ }^{6}$. Homilia wśród wielu innych podejmuje również zagadnienie przebaczenia. Celem niniejszego opracowania jest przedstawienie szczególnej roli homilii w wychowaniu do przebaczenia. W kolejnych punktach zostaną omówione kwestie homilisty jako wychowawcy, wychowawczej roli homilii oraz - zagadnienie centralne - homilii o przebaczeniu. W końcowej części opracowania zaprezentowane zostaną również sugestie nowowydanego Dyrektorium homiletycznego, dotyczące zagadnienia przepowiadania na temat przebaczenia.

\section{Homilista jako wychowawca}

Obowiązkiem wspólnoty chrześcijańskiej ,jest przekazywanie wartości chrześcijańskich i doprowadzenie do poznania Osoby Chrystusa, który wzywa każdego człowieka, by żył coraz piękniej i by odkrył zbawienie i szczęście, które On nam daje [...]. Niech chrześcijanie nie boją się głosić nowym pokoleniom Chrystusa, źródła nadziei i światła na ich drodze!"’. Każdy człowiek ma prawo oczekiwać od społeczności wierzących, od Kościoła pomocy w zdobywaniu pełnej doskonałości ludzkiej ${ }^{8}$. To zadanie pomagania człowiekowi w systematycznym doskonaleniu postawy chrześcijańskiej należy do podstawowych obowiązków homilisty. Według najnowszej teologii homiletycznej współczesny głosiciel słowa Bożego podczas homilii powinien realizować wiele funkcji. Do najczęściej wymienianych należą: herol-

5 Jan Przybyłowski, „Deklaracja o wychowaniu chrześcijańskim Gravissimum educationis: wskazówki pastoralne dla funkcji wychowawczej Kościoła", Warszawskie Studia Pastoralne 5 (2007): 45, 46.

${ }^{6}$ Henryk Sławiński, „Wychowawcze znaczenie homilii ślubnej”, Teologia i Moralność 12 (2012): 106.

7 Jan Paweł II, „Wychowanie młodego pokolenia zadaniem wszystkich. Do uczestników europejskiego sympozjum na temat: «Wyzwania edukacji» (3 VII 2004)", L'Osservatore Romano 11 (2004): 22.

${ }^{8}$ Przybyłowski, „Deklaracja”, 45, 46. 
da, proroka, tłumacza, interpretatora, świadka, mistagoga, retora, nadawcy, terapeuty i wychowawcy ${ }^{9}$.

Podstawowym zadaniem stojącym przed homilistą jest głoszenie całości zasad życia chrześcijańskiego w kilkuletnim cyklu, a więc głoszenie tego, co należy czynić dla chwały Bożej i zbawienia człowieka (KPK, kan. 768, § 1). Homilista $\mathrm{w}$ głoszonym słowie ma pobudzić wiernych do przemiany życia oraz do odpowiedzi na usłyszane słowo Boże. Słowo to jest owocne wtedy, kiedy stosowane jest w praktyce życia codziennego. Dlatego homilia, będąc pokarmem koniecznym dla podtrzymania chrześcijańskiego życia (Ogólne wprowadzenie do Mszału Rzymskiego, 65), ma ukazywać różne możliwości odpowiedzi na Boże wezwanie w codziennym życiu. Słuchacz powinien dowiedzieć się o tym, jak może realizować swoją wiarę we współczesnym świecie. Wymaga to zmiany sposobu myślenia, burzenia postaw i zachowań niezgodnych z duchem Chrystusa, wywoływania postaw prawdziwie chrześcijańskich oraz wprowadzenia odnowionego porządku życia moralnego członków wspólnoty. Kongregacja ds. Kultu Bożego i Dyscypliny Sakramentów 10 lutego 2015 roku zaprezentowała Dyrektorium homiletyczne. Dokument ten, odwołujac się do nauczania soborowego, zaznacza, że homilia, będąc „wyjaśnieniem słowa Pisma Świętego, które zostało odczytane, czy też jakiegoś tekstu liturgicznego, winna prowadzić wspólnotę wiernych do czynnego sprawowania Eucharystii, tak «aby przestrzegali w życiu zobowiązań płynących z sakramentu, który z wiarą przyjęli» (KL 10)” (DH 10). Kolejny punkt tego dokumentu zaznacza, że „w najszerszym znaczeniu homilia jest wypowiedzią o tajemnicach wiary i prawidłach życia chrześcijańskiego dopasowaną do szczególnych potrzeb słuchaczy" (DH 11).

Homilista-wychowawca ma realizować podstawowy cel kościelnej posługi słowa, który najpełniej określił Jezus Chrystus słowami nakazu misyjnego: „Idźcie na cały świat i głoście Ewangelię wszelkiemu stworzeniu! Kto uwierzy i przyjmie chrzest będzie zbawiony; a kto nie uwierzy, będzie potępiony" (Mk 16, 15-16). Celem przepowiadania słowa Bożego jest wiara i życie z wiary, autentyczna wspólnota w Chrystusie, czyli Kościół, a w ostateczności uwielbienie Boga i zbawienie ludzi ${ }^{10}$. Homilista, wyposażony

9 Wiesław Przyczyna, „Kaznodzieja jako herold”, w: Stuga Słowa, red. Wiesław Przyczyna (Kraków: Wydawnictwo „Poligrafia Salezjańska”, 1997), 51. Funkcję kaznodziei jako wychowawcy omawia artykuł: Janusz Tarnowski, „Kaznodzieja jako wychowawca”, w: Stuga Słowa, red. Wiesław Przyczyna (Kraków: Wydawnictwo „Poligrafia Salezjańska”, 1997), 153-164.

${ }^{10}$ Antoni Lewek, Współczesna odnowa kaznodziejstwa. Z najnowszych dziejów ruchu homiletycznego, t. 1 (Warszawa: Akademia Teologii Katolickiej, 1980), 61. 
w mandat Kościoła, powinien głosić wiarę, przygotowywać do przyjęcia sakramentów, uczyć wypełniania wskazań Chrystusa, a także zachęcać do pobożności, apostolstwa i dzieł miłości (KL 9, 10). Głoszenie słowa Bożego powinno pomnażać chwałę Bożą i wzbogacać w ludziach Boże życie. Celem przepowiadania słowa Bożego jest prowadzenie dalej dzieła samego Chrystusa, który przyszedł na świat, aby dać świadectwo prawdzie (KDK 3) ${ }^{11}$. Ostatecznym celem przepowiadania słowa Bożego jest zbawienie, do którego dochodzi się poprzez nawrócenie i wiarę we wspólnocie Kościoła. Homilista przykład takiego przepowiadania wzywającego do radykalnej przemiany życia czerpie od Jezusa Chrystusa, który od samego początku swojej publicznej działalności wzywa do nawrócenia (Mk 1, 15). Podobnie wezwaniem do nawrócenia nacechowane było przepowiadanie Apostołów (por. Dz 2, 38). W nawróceniu tym nie tyle chodzi o wymiar moralny, ile o zmianę podstawowej opcji życiowej, wejście na inną, nową drogę życia. Ta nowa droga związana jest z koniecznością zmiany dotychczasowego życia oraz wyborem Jezusa Chrystusa za Pana swego życia. W tym kontekście mówimy o drugim nawróceniu, które jest nieustannym zadaniem całego Kościoła (Katechizm Kościoła katolickiego (dalej: KKK), 1428) ${ }^{12}$.

Homilista jako wychowawca ma na celu doprowadzenie słuchaczy do udziału w tajemnicy Chrystusa, co dokonuje się przez doprowadzenie u słuchaczy słowa Bożego do wewnętrznej przemiany. Najpierw musi to być zmiana sposobu myślenia, burzenie dotychczasowych postaw i zachowań niezgodnych z duchem Chrystusa, wywoływanie postaw prawdziwie chrześcijańskich i na końcu wprowadzenie odnowionego porządku życia moralnego słuchaczy. Systematyczna przemiana człowieka, do której wzywa homilista-wychowawca, oznacza wszechstronny i pełny rozwój osobowości, przygotowanie do odpowiedzialnego podjęcia powołania. Punktem wyjścia jest kontakt osobowy z Bogiem, a celem - realizacja osobowości chrześcijańskiej. To kształtowanie, wychowywanie dokonuje się tak na płaszczyźnie przyrodzonej, jak i nadprzyrodzonej ${ }^{13}$.

${ }^{11}$ Leszek Szewczyk, Recepcja liturgicznego wymiaru homilii. Studium homiletyczne na podstawie badań kaznodziejstwa kapłanów Archidiecezji Katowickiej w latach 1972-1999 (Katowice: Księgarnia św. Jacka, 2003), 23, 24.

12 Gerard Siwek, „Przepowiadanie słowa Bożego”, w: Teologia pastoralna, t. 2, red. Ryszard Kamiński (Lublin: Wydawnictwo Atla 2, 2002), 151.

${ }_{13}$ Na płaszczyźnie naturalnej droga do rozwoju indywidualnego i społecznego wiedzie przez: kształtowanie osoby ludzkiej do dojrzałego podejmowania odpowiedzialności; wychowanie osoby do właściwego rozumienia wolności i stopniowe wprowadzanie jej w życie; kształtowanie prawidłowego sumienia, które winno być prawdziwe, pewne i delikatne; rozwi- 


\section{Wychowaweza rola homilii}

W praktyce kaznodziejskiej wypowiedź ta przyjmuje dwie zasadnicze postacie: homilii i kazania. Homilia w posoborowym ujęciu stanowi szczególną postać głoszenia Słowa Bożego. Według oficjalnych wypowiedzi Kościoła przez homilię rozumie się taką formę przepowiadania Słowa Bożego, która stanowi część samej liturgii, tworzy z nią jeden akt kultu. Opiera się na tekście świętym, czyli pochodzącym z części stałych lub własnych Mszy św., wprowadza w sprawowaną liturgię oraz uwzględnia szczególne potrzeby słuchaczy w dziedzinie wiary i życia chrześcijańskiego. Homilia łączy w sobie trzy elementy, które decydują o jej istocie. Pierwszym jest sprawowane misterium, drugim jest tekst biblijny ze swoim orędziem i jego aktualizacja, trzecim aktualna sytuacja życiowa konkretnych słuchaczy. Przepowiadane orędzie zbawienia powinno łączyć się z liturgią, a jedno i drugie z życiem słuchaczy ${ }^{14}$. Tak rozumiana homilia pomaga wiernym rozpoznać znaki cza$\mathrm{su}$, a następnie odpowiedzieć na nie z wiarą zarówno podczas liturgii, jak również poza nią przez życie odpowiadające wymaganiom Ewangelii ${ }^{15}$.

Homilijne głoszenie Słowa Bożego, czerpiąc z inspiracji biblijnych, nie polega na przekazywaniu kodeksu zachowań moralnych, lecz na budowa-

janie naturalnego dążenia do poznania i kochania Boga, gdyż każdy człowiek posiada dążność i prawo do szukania i poznania Boga przy pomocy światła rozumu. Zaś w sferze wartości nadprzyrodzonych rozwój człowieka, który ma się dokonywać przez działanie odpowiednio dobranych treści i oddziaływania głosiciela słowa Bożego, powinien uwzględniać: świadomość powołania życiowego i otrzymanego daru wiary. To budzenie świadomości powołania jest istotnym zadaniem głoszącego. Wszyscy ludzie są powołani przez Stwórcę do zbawienia, człowiek świadomy swego religijnego powołania i daru wiary ma prawo do wewnętrznej przemiany, tak że z grzesznika staje się sprawiedliwym, z nieprzyjaciela - przyjacielem Boga; przez przemianę wewnętrzną wiernych ma się dokonywać stopniowo przemiana społeczności, do której wierni należą; stały wzrost Mistycznego Ciała Chrystusa, czyli Kościoła. Dokonuje się to przez wzrost rodzin, które stanowią „Kościół domowy”; przez działalność wierzących w duchu Chrystusa dokonuje się uświęcanie świata (consecratio mundi) - zwłaszcza przez świadectwo życia i świadectwo nadziei. Zob. Marian Gosek, „Tworzywo homiletyczne”, w: Praktyka przepowiadania słowa Bożego. Materiały do nauczania w zakładach teologicznych, red. Leszek Kuc, t. 2 (Warszawa: Akademia Teologii Katolickiej, 1973), 356-360.

14 Włodzimierz Broński, „Homilia”, w: Leksykon teologii pastoralnej, red. Ryszard Kamiński, Wiesław Przygoda, Marek Fijałkowski (Lublin: Towarzystwo Naukowe Katolickiego Uniwersytetu Lubelskiego Jana Pawła II, 2006), 288.

15 Sławiński, „Wychowawcze znaczenie”, 106. 
niu posiadającej personalny i dialogiczny charakter wiary. Odpowiedź, jakiej człowiek udziela Bogu, polega przede wszystkim na osobowej więzi ze Stwórcą. Jak uczy Benedykt XVI, „u początku bycia chrześcijaninem nie ma etycznej czy jakiejś wielkiej idei, ale natomiast spotkanie z wydarzeniem, z Osobą, która nadaje życiu nową perspektywę, a tym samym decydujące ukierunkowanie" (Deus caritas est 1 ).

Wychowywanie słuchaczy do wypełniania w codziennym postępowaniu zasad życia chrześcijańskiego powinno być wierne orędziu biblijnemu, winno zatem opierać się na schemacie: indykatyw zbawczy - imperatyw moralny. Zachęty kierowane podczas homilii do właściwych postaw moralnych (imperatyw moralny) powinny być w homilii wyprowadzone z orędzia o zbawczym działaniu Boga przez Chrystusa (indykatyw zbawczy) oraz zaproszenia do osobistego przylgnięcia do Niego. Proces wychowawczy w homilii dokonuje się między innymi poprzez wymagania stawiane człowiekowi, które zawsze powinny być poprzedzone doświadczeniem Bożego działania w życiu człowieka ${ }^{16}$.

Wychowawcza rola homilii polega, tak jak każda inna działalność wychowawcza, na kształtowaniu u słuchaczy określonych pojęć, uczuć, postaw i dążeń. Homilia dąży do utrwalenia właściwych wartości religijno-moralnych u słuchaczy oraz zachęca ich do osiągnięcia osobistej i społecznej dojrzałości religijno-moralnej, która przejawia się w trosce o rozwój wiary, świadomy i czynny udział w liturgii Kościoła, pielęgnowanie cnót chrześcijańskich oraz kierowanie się w życiu miłością ${ }^{17}$. Homilia powinna prowadzić do przemiany życia poszczególnych słuchaczy słowa Bożego, pomagając w udzielaniu odpowiedzi wierzącym na usłyszane słowo. Dlatego ma ona wskazywać na możliwe sposoby odpowiedzi na Boże wezwanie w codziennym życiu. Słuchacz powinien usłyszeć o tym, jak jego wiara ma być realizowana we współczesnym świecie, i musi wiedzieć, że Bóg postawił mu określone zadania oraz oczekuje na nie odpowiedzi. Odpowiedź ta realizuje się na trzech płaszczyznach ludzkiego życia: wiary, nawrócenia i miłości. Homilia, która jest jedynie pouczeniem dotyczącym tekstu biblijnego, a nie zawiera jednocześnie nakłaniania, napominania i umacniania, nie spełnia swego zasadniczego zadania. Współczesne głoszenie Ewangelii musi polegać na starannym odczytaniu prawd objawionych, które wyrastają z niej w kontekście

${ }^{16}$ Leszek Szewczyk, „Zagadnienia moralne w wypowiedzi kaznodziejskiej”, Śląskie Studia Historyczno-Teologiczne 2 (2004): 51.

17 Sławiński, „Wychowawcze znaczenie”, 109. 
nowego świata, nowej sytuacji społecznej, nowych zagrożeń człowieka. To głoszenie powinno być przeniknięte nową interpretacją starych prawd. To poszczególne perykopy Lekcjonarza za każdym razem sugerują homiliście i słuchaczowi konkretny, klarowny i aktualny moralny apel ${ }^{18}$.

W drugiej części Katechizmu Kościoła Katolickiego, w której mowa jest o celebracji misterium chrześcijańskiego, przypomniana została zachęta, że zgromadzenie wiernych powinno przygotować się na spotkanie ze swoim Panem po to, by być

ludem dobrze usposobionym. To przygotowanie serc jest wspólnym dziełem Ducha Świętego i zgromadzenia, a szczególnie pełniących funkcje wynikające ze święceń. Łaska Ducha Świętego zmierza do wzbudzenia wiary, nawrócenia serca i przylgnięcia do woli Ojca. Te dyspozycje są podstawą do przyjęcia innych łask ofiarowanych w samej celebracji oraz owoców nowego życia, jakie ma ono następnie wydać (KKK 1098).

Wzbudzenie wiary, nawrócenie serca i przylgnięcie do woli Ojca to z całą pewnością również zadania stojące przed przepowiadaniem homilijnym.

W adhortacji apostolskiej o Słowie Bożym w życiu i misji Kościoła Verbum Domini z 2010 roku papież Benedykt XVI zachęca do coraz większego odkrywania konieczności i piękna głoszenia Słowa. „Wszyscy dostrzegamy, jak ważne jest, by światło Chrystusa oświecało każde środowisko człowieka: rodzinę, szkołę, kulturę, pracę, czas wolny i inne dziedziny życia społecznego. Trzeba głosić nie jakieś słowo pociechy, lecz słowo, które porusza, wzywa do nawrócenia, umożliwia spotkanie z Nim, dzięki któremu rozkwita nowa ludzkość" (VD 93).

Słowa homilii, będąc żywym Słowem Boga, zawartym w Piśmie świętym, są dynamiczne i mają ogromną moc. Głównym warunkiem skuteczności homilii jest wierność Bożemu objawieniu, które zostało przekazane Kościołowi, aby je strzegł, przekazywał i wiernie wyjaśniał (KO 10). Kościół dokonał selekcji tekstów Objawienia na potrzeby liturgii. Teksty te umieszczone w Lekcjonarzu mszalnym zyskały nowy, liturgiczny kontekst, który determinuje również sposób odczytania tekstów biblijnych. Układ Lekcjonarza sprawia, że z treściowego bogactwa tekstów biblijnych wydobywa się jeden lub dwa główne tematy. Sam wybór tekstów biblijnych ma znaczenie wychowawcze, a w przygotowaniu homilii ważna jest także ,wszelka peda-

${ }^{18}$ Szewczyk, „Zagadnienia moralne”, 55. 
gogia, z jaką Kościół czyta i interpretuje słowo Boże w różnych okresach roku liturgicznego" 19 .

\section{Homilie o przebaczeniu}

W encyklice Dives in misericordia Jan Paweł II zwraca uwagę, że świat, z którego zostałoby wyeliminowane przebaczenie i pojednanie, stałby się światem zimnej, bezdusznej sprawiedliwości, w imię której każdy dochodziłby swoich praw, zaś drzemiący w różnej postaci ludzki egoizm wprowadzałby prawo i racje silniejszych, czyniłby społeczeństwa areną ustawicznej konfrontacji i walki ${ }^{20}$. Powinnością Kościoła jest „,strzec prawdziwości przebaczenia w życiu i postępowaniu, w wychowaniu i duszpasterstwie. Strzeże zaś nie inaczej, jak strzegąc tego źródła - czyli tajemnicy miłosierdzia Boga samego objawionej w Jezusie Chrystusie" (DiM 14) ${ }^{21}$. Kościół posiada misję pojednawczą, która polega na pojednaniu człowieka z samym sobą, następnie z bliźnimi i wreszcie z całym stworzeniem. Misja ta związana jest z głoszeniem konieczności nawrócenia serc i pokonania egoizmu w samym człowieku, przebaczenia doznanych niesprawiedliwości we wnętrzu grup społecznych, zwalczenia wszelkiego nieopanowania w posiadaniu dóbr, opanowania chęci wyzysku wraz z niepohamowaną żądzą i pogonią za przy-

19 Kongregacja ds. Duchowieństwa, Kapłan głosiciel słowa, szafarz sakramentów i przewodnik wspólnoty $w$ drodze do trzeciego tysiąclecia chrześcijaństwa (Tarnów: Wydawnictwo Diecezji Tarnowskiej Biblos, 1999) rozdz. II punkt 2; zob. Stanisław Dyk, „Orędzie homilijne w okresie zwykłym w ciągu roku cyklu B”, Roczniki Liturgiczno-Homiletyczne 1 (2010): 17.

${ }^{20}$ Zbigniew Narecki, „Wartość przebaczenia i pojednania w pryzmacie współczesności”, Pedagogia Ojcostwa 1 (2015): 48.

${ }^{21}$ Interesujące wnioski praktyczne, wynikające z nauczania Jezusa Chrystusa na temat przebaczenia, przedstawia Janusz Kręcidło. Mogą one być cenną inspiracją dla homilistów podejmujących ten temat. Zdaniem tego autora umiejętność przebaczania bliźnim doznanych od nich krzywd to cecha pozwalająca odróżnić ucznia Jezusa od poganina. Na miano chrześcijanina nie zasługuje ten, kto nie potrafi przebaczać, bowiem chrześcijanin, sam obdarowany przebaczeniem, jest zobowiązany do przebaczania wzajemnych przewinień (np. Mt 18, 21; Ef 4, 32; Kol 3, 12n). Nauczanie Jezusa na temat przebaczenia stanowi spójny system, uwydatniający obowiązek dążenia do przebaczenia i pojednania i to zarówno ze strony krzywdziciela, jak i pokrzywdzonego. Jezus Chrystus jest nauczycielem, przykładem i autorem przebaczenia, co sprawiło, że przebaczenie zakorzenione w kerygmacie o męce, śmierci i zmartwychwstaniu Chrystusa ma głęboki wymiar teologiczny. Ostatnim wnioskiem wspomnianego autora jest stwierdzenie, że „ten, kto odmawia bliźniemu przebaczenia, nie otrzyma go od Boga” (np. Mt 6, 12. 14-15; 18, 23n). Kręcidło, „Jakiego przebaczenia”, 32. 
jemnościami lub dominacją nad drugimi. „Środków tej ewangelizacyjnej odnowy jest cała gama w następujących zakresach: przepowiadania Słowa Bożego, sprawowania Kultu i Sakramentów, szerzenia Miłości i Diakonii Miłosierdzia. W dziele tym priorytet uzyskuje sakrament Pojednania"22.

Każda homilia głosi konieczność przemiany swojego serca, nawrócenia. W procesie nawrócenia miejsce centralne zajmuje przebaczenie. Konieczność przebaczenia wynika z faktu przebaczenia człowiekowi przez Boga. Jeżeli człowiek dopuści ,do «wyschnięcia» przebaczenia, to narazi się na niepowodzenie i na brak rozwoju. Pomiędzy życiem duchowym a przebaczeniem, rozpatrywanym w aspekcie daru Bożego, istnieje jakaś tajemnicza zależność, podobnie jak między przebaczeniem a nawróceniem"²3.

Centralnym tematem przepowiadania homilijnego jest Bóg, który tak umiłował świat, że dał swojego Jednorodzonego Syna, aby go zbawił. Miłość ta jest miłością oczekującą, przebaczającą i zbawiającą, a Królestwo Boże to Królestwo miłosierdzia, pokoju i radości. Z całą pewnością centrum chrześcijańskiego nauczania nie jest grzech. W przypowieści o synu marnotrawnym, dziecku, które popełnia ciężki grzech opuszczając ojca, centralnym tematem nie jest słabość ludzka, ale ogrom miłości Ojca, który oczekuje syna, przyjmuje z miłosierdziem i wyprawia wspaniałą uc ztę dla już nawróconego. „Centralnym tematem Dobrej Nowiny jest więc miłość Ojca"24. Także inne przypowieści ewangelijne w centrum stawiają Boga miłującego człowieka. To przekonanie wyraża papież Franciszek:

W przypowieściach poświęconych miłosierdziu Jezus objawia naturę Boga jako naturę Ojca, który nigdy nie uważa się za zwyciężonego, dopóki nie sprawi, że poprzez współczucie i miłosierdzie zniknie grzech i pokonane zostanie odrzucenie. Znamy te przypowieści, a szczególnie trzy z nich: przypowieść o zaginionej owcy, o zagubionej monecie i o synu marnotrawnym (por. Łk 15, 1-32). W tych przypowieściach Bóg zawsze przedstawiony jest jako pełen radości, przede wszystkim, gdy przebacza. Znajdujemy w nich istotę Ewangelii oraz naszej wiary, ponieważ miłosierdzie jest ukazane jako siła, która zwycięża wszystko, która wypełnia serce miłością i pociesza przebaczeniem ${ }^{25}$.

22 Narecki, „Wartość przebaczenia”, 44.

${ }^{23}$ Stanisław Urbański, „Przebaczenie źródłem uzdrowienia i przemiany życia”, Zeszyty Formacji Duchowej 14 (2000): 53, 54.

${ }^{24}$ Krzysztof Wons, „Miłość Słowa i złość grzechu”, Zeszyty Formacji Duchowej 14 (2000): 115.

${ }^{25}$ Franciszek, Misericordiae vultus. 
Konkretną wskazówkę dla głosicieli słowa Bożego znajdujemy w dalszej części bulli Misericordiae vultus:

Przebaczenie zniewag staje się najbardziej ewidentnym wyrazem miłości miłosiernej, a dla nas chrześcijan jest nakazem, którego nie możemy pominąć. Jakże wydaje się nieraz trudne to przebaczenie! A jednak jest ono narzędziem złożonym w nasze ręce, abyśmy byli w stanie osiągnąć spokój serca. Porzucić żal, złość, przemoc i zemstę - to warunki konieczne do tego, by żyć szczęśliwie. Przyjmujemy zatem zachętę Apostoła: „Niech słońce nie zachodzi nad waszym gniewem" (Ef 4, 26)

W adhortacji apostolskiej Evangelii Gaudium papież Franciszek podkreśla, że zgodnie z planem miłości Ojca bycie Kościołem oznacza bycie Ludem Bożym. To rodzi konieczność głoszenia i niesienia

Bożego zbawienia w ten nasz świat, który często się gubi, potrzebuje odpowiedzi zachęcających, dających nadzieję, nowe siły, by podążać w drodze. Kościół powinien być miejscem bezinteresownego miłosierdzia, w którym wszyscy mogą się czuć przyjęci, kochani, w którym mogą doświadczyć przebaczenia i być zachęceni do życia zgodnego z Ewangelią (EG 114).

Przepowiadanie homilijne to proklamacja zbawczych dzieł Bożych, wyrastająca z Pisma Świętego, które jest jego podstawą. W sprawowaniu liturgii Słowo Boże stanowi element konieczny. Czytania z Pisma Świętego są objaśniane w homilii, z niego też pochodzą psalmy przeznaczone do śpiewu. To w liturgii Bóg przemawia do swego ludu, Chrystus głosi Ewangelię, a lud odpowiada Stwórcy śpiewem i modlitwą (KL 33). Homilia, wyjaśniając odczytane słowa Pisma świętego lub jakiś tekst liturgiczny, powinna prowadzić wspólnotę wiernych do czynnego sprawowania Eucharystii tak, aby zgromadzeni zachowywali w życiu to, co otrzymali przez wiarę (KL 10).

Homilista, zachęcając do nawrócenia, wielokrotnie spotyka się z tekstami Pisma świętego, które mówią o Bogu przebaczającym. Fragment z Księgi Izajasza: „Niechaj bezbożny porzuci swą drogę i człowiek nieprawy swoje knowania. Niech się nawróci do Pana, a Ten się nad nim zmiłuje, i do Boga naszego, gdyż hojny jest w przebaczaniu", odczytywany jest w święto Chrztu Pańskiego roku B (Iz 55, 1-11 - Nowe $i$ wieczne przymierze ${ }^{27}$ : „Niech się

\footnotetext{
26 Tamże.

27 Nagłówki pochodzą od redaktorów lekcjonarza mszalnego.
} 
nawróci do Pana, a Pan się nad nim zmiłuje, i do Boga naszego, gdyż hojny jest w przebaczaniu" - Iz 55, 7b), w Wigilię paschalną (Iz 55, 1-11 - Nowe $i$ wieczne przymierze), 25. niedzielę zwykłą roku A (Iz 55, 6-9-Myśli moje nie sa myślami waszymi) oraz w czytaniach mszy o odpuszczenie grzechów (Iz 55, 6-9-Nawróćcie się do Boga, gdyż hojny jest w przebaczaniu). W Uroczystość Najświętszej Trójcy roku A odczytywany jest fragment mówiący o Bogu przebaczającym (Wj 34, 4b-6. 8-9-Bóg objawia się Mojżeszowi: „I natychmiast skłonił się Mojżesz aż do ziemi i oddał pokłon, mówiąc: «Jeśli łaskawy jesteś dla mnie, Panie, niech pójdzie Pan w pośrodku nas. Jest to wprawdzie lud o twardym karku, ale przebaczysz winy nasze i grzechy nasze i uczynisz nas swoim dziedzictwem»" - Wj 34, 8-9). Ten sam fragment Księgi Wyjścia odczytywany jest również w czytaniach mszy o Najświętszym Sercu Pana Jezusa (Wj 34, 4b-6. 8-9 - Bóg miłosierny i litościwy). W poniedziałek 8. tygodnia zwykłego, rok I, w czytaniu mowa jest o Bogu przebaczającym wszystkim, którzy dążą do nawrócenia (Syr 17, 24-29 Prawdziwe nawrócenie: ,Jakże wielkie jest miłosierdzie Pana i przebaczenie dla tych, którzy się do Niego nawracają" - Syr 17, 29).

W czytaniach na 17. niedzielę zwykłą roku C homilista może odnieść się do fragmentu opisującego postawę Abrahama wstawiającego się u Boga za mieszkańcami Sodomy (Rdz 18, 20-32-Abraham wstawia się za Sodoma: „Może w tym mieście jest pięćdziesięciu sprawiedliwych; czy także zniszczysz to miasto i nie przebaczysz mu dla owych pięćdziesięciu sprawiedliwych, którzy w nim mieszkają? - Rdz 18, 24). Powyższy fragment znajduje się również w czytaniach przeznaczonych na poniedziałek 11. tygodnia zwykłego, rok I (Rdz 18, 16-33).

Fragmenty Starego Testamentu zawierające modlitwy o przebaczenie odczytywane są w piątek 3. tygodnia wielkiego postu (Oz 14, 2-10 - Wróć do Pana Boga twojego: „Mówcie do Niego: «Przebacz nam całą naszą winę, w ten sposób otrzymamy dobro za owoc naszych warg»" - Oz 14, 3b). Ten sam fragment czytań z Księgi Ozeasza występuje także w piątek 14. tygodnia zwykłego, roku drugiego. Podobna treść modlitwy znajduje się w czytaniach na wtorek 5. tygodnia zwykłego, rok II (1 Krl 8, 22-23. 27-30 - Modlitwa Salomona w czasie poświęcenia świątyni: „Dlatego wysłuchaj błaganie Twego sługi i Twego ludu, Izraela, ilekroć modlić się będzie na tym miejscu. Ty zaś wysłuchaj na miejscu Twego przebywania w niebie. Nie tylko wysłuchaj, ale też i przebacz" - $1 \mathrm{Krl} 8,30$ ).

W Nowym Testamencie przebaczenie bliźnim win staje się jednym z najważniejszych tematów nauczania Jezusa. Nowe akcenty w Jezusowym nauczaniu o przebaczeniu zawierają się zwłaszcza w słowach o odpuszcze- 
niu grzechów $(\mathrm{Mk} 2,5)$ oraz w prośbie o przebaczenie skierowanej do Ojca w modlitwie Ojcze nasz (Mt 6, 12; por. Łk 23, 34; Dz 7, 60) ${ }^{28}$.

Homilista może odwoływać się do tematyki przebaczenia, analizując Ewangelię przypadająca na 17. niedzielę zwykłą roku C (Łk 11, 1-13-Chrystus uczy modlitwy: „Naszego chleba powszedniego dawaj nam na każdy dzień, i przebacz nam nasze grzechy, bo i my przebaczymy każdemu, kto nam zawini; i nie dopuść, byśmy ulegli pokusie" - Łk 11, 4). Perykopa powyższa występuje również w środę 27. tygodnia zwykłego. We wtorek I tygodnia wielkiego postu homilista może odwołać się do Jezusowej zachęty do przebaczenia (Mt 6, 7-15-Jezus uczy, jak się modlić: „Jeśli bowiem przebaczycie ludziom ich przewinienia, i wam przebaczy Ojciec wasz niebieski. Lecz jeśli nie przebaczycie ludziom, i Ojciec wasz nie przebaczy wam waszych przewinień" - Mt 6,14$)$. Ta sama perykopa przypada również na czwartek 11. tygodnia zwykłego. Lekcjonarz mszalny czterokrotnie przywołuje Chrystusową przypowieść o niemiłosiernym słudze: 24. niedziela zwykła roku A (Mt 18, 21-35 - Przypowieść o niemiłosiernym słudze: „Panie, ile razy mam przebaczać, jeśli mój brat wykroczy przeciwko mnie? Czy aż siedem razy? Jezus mu odrzekł: «Nie mówię ci, że aż siedem razy, lecz aż siedemdziesiąt siedem razy» - Mt 18, 22). Powyższa perykopa występuje także w czytaniach przypadających we wtorek 3. tygodnia wielkiego postu, czwartek 19. tygodnia zwykłego oraz w czytaniach mszy o zjednoczenie chrześcijan (Mt 18, 19-22).

Na konieczność przebaczenia wskazują również czytania z 19. niedzieli zwykłej roku B (Ef 4, 30-5, 2 - Naśladować Boga, który objawit swoja mitość w Chrystusie: „Przebaczajcie sobie nawzajem, tak jak i Bóg nam przebaczył w Chrystusie" - Ef 4, 32). Powyższe słowa występują również we fragmencie czytania przypadającego $\mathrm{w}$ poniedziałek 30 . tygodnia zwykłego (Ef 4, 32-5, 8) oraz w czytaniach mszy o zjednoczenie chrześcijan (Ef 4, 30$-5,2)$. Podobna zachęta znajduje się w czytaniach z piątku 8. tygodnia zwykłego (Mk 11, 11-25 - Nieurodzajna figa. Oczyszczenie świątyni: „A kiedy stajecie do modlitwy, przebaczcie, jeśli macie co przeciw komu, aby także Ojciec wasz, który jest w niebie, przebaczył wam wykroczenia wasze" Mk 11, 25) oraz poniedziałku 32. tygodnia zwykłego (Łk 17, 1-6-Obowiqzek przebaczania: „Jeśli brat twój zawini, upomnij go; i jeśli żałuje, przebacz

${ }^{28}$ Friedrich Vinzenz Reiterer, „Odpuszczenie grzechów/Przebaczenie”, w: Nowy leksykon biblijny, red. Franz Kogler, Renate Egger-Wenzel, Michael Ernst (Kielce: Wydawnictwo „Jedność”, 2011): 543. 
mu. I jeśliby siedem razy na dzień zawinił przeciw tobie i siedem razy zwróciłby się do ciebie, mówiąc: «Żałuję tego», przebacz mu" - Łk 17, 3-4).

Motywy związane z obrazem Boga przebaczającego oraz o konieczności przebaczenia wzajemnego znajdujemy w liturgii słowa z Niedzieli Świętej Rodziny Jezusa, Maryi i Józefa (Kol 3, 12-21 - Chrześcijańskie zasady życia domowego: „Jako wybrańcy Boży, święci i umiłowani, obleczcie się w serdeczne miłosierdzie, dobroć, pokorę, cichość, cierpliwość, znosząc jedni drugich i wybaczając sobie nawzajem, jeśliby miał ktoś zarzut przeciw drugiemu: jak Pan wybaczył wam, tak i wy" - Kol 3, 12).

Z Pisma Świętego pochodzą psalmy przeznaczone do śpiewu. To w liturgii Bóg przemawia do swego ludu, Chrystus głosi Ewangelię, a lud odpowiada Stwórcy śpiewem i modlitwą (KL 33). Słowa Psalmu 130(129): „Jeśli zachowasz pamięć o grzechach, Panie, Panie, któż się ostoi? Ale Ty udzielasz przebaczenia, aby Ci służono z bojaźnią" - Ps 130(129), 3-4, w lekcjonarzu występują pięciokrotnie. Za każdym też razem mogą stanowić cenne źródło przepowiadania homilijnego na temat przebaczenia.

Homiliści w przepowiadaniu na temat przebaczenia mogą również odwołać się do stałych lub zmiennych części mszy św. Sama liturgia mszy św. (wstępne pozdrowienie, kolekta, modlitwa eucharystyczna, Modlitwa Pań$s k a$, modlitwa po komunii) zawiera bardzo bogate źródło inspiracji dla przepowiadania homilijnego ${ }^{29}$. Mszał Rzymski zawiera aż 38 próśb o przebaczenie. Znajdują się one między innymi w antyfonach na wejście (4 prośby), kolektach (7), modlitwach nad darami (14) oraz w prefacjach 1 i 2 modlitwy eucharystycznej o tajemnicy pojednania.

Źródła biblijne i liturgiczne odwołujące się do problematyki przebaczenia są wielokrotnie przywoływane w Lekcjonarzu Mszalnym oraz Mszale Rzymskim. Homiliści zatem mają wiele okazji, żeby, poddając analizie czytania mszalne, stałe i zmienne części mszy świętej, precyzyjnie omówić to zagadnienie. Oczywiście ważne jest, żeby w analizie tych źródeł i ich interpretacji byli zgodni z nauczaniem Kościoła ${ }^{30}$.

29 II Polski Synod Plenarny (Poznań-Warszawa: Wydawnictwo Pallotinum, 1991), 85.

${ }^{30}$ Na niebezpieczeństwo fałszywych interpretacji wskazuje Peter Gumple: „Na podstawie swojej wypróbowanej kompetencji i doświadczenia nie będą oni przynajmniej narażać się na niebezpieczeństwo popełnienia błędów tak powszechnych wśród dyletantów, jak nieuwzględnienie konkretnych okoliczności i mentalności czasów oraz anachroniczne ocenianie ich na podstawie kryteriów dzisiaj uważanych za ważne. Ta uwaga ma ogromne znaczenie. Już niejednokrotnie słyszałem stwierdzenia wypowiadane przez kaznodziejów i prelegentów, którzy oczywiście nie mając odpowiedniego przygotowania i w wyraźnej sprzeczności z prawdą historyczną, przepraszali i prosili o przebaczenie, publicznie oraz w imieniu Kościoła, za 


\section{Wskazania nowego Dyrektorium homiletycznego}

Cennych sugestii dotyczących przepowiadania homilijnego na temat przebaczenia dostarcza również Dyrektorium homiletyczne. Dyrektorium to zaleca korzystanie w wyborze problematyki moralnej z Katechizmu Kościota Katolickiego. W aneksie do Dyrektorium powiązano „kerygmat czytań poszczególnych niedziel i świąt trzyletniego cyklu roku liturgicznego z wybranymi fragmentami katechizmu. Aneks ten jest więc przykładem łączenia orędzia tekstów świętych: biblijnych i liturgicznych z Tradycją i nauczaniem Nauczycielskiego Urzędu Kościoła"31. Homilista, korzystając z Katechizmem Kościoła Katolickiego, może w ten sposób ,pomóc swoim słuchaczom w połączeniu słowa Bożego, wiary Kościoła, moralnych wymagań Ewangelii oraz ich duchowości osobistej i liturgicznej" (DH 160). Punkt 145 Dyrektorium wskazuje na kerygmat perykop ewangelijnych czytanych w roku C.

Nauka właściwa Ewangelii Łukaszowej dotyczy przede wszystkim łagodności i gotowości do wybaczenia, które znamionowały działalność Chrystusa. Wszyscy, którzy spotykają Jezusa między rozpoczęciem Jego posłannictwa a Jego drogą do Jerozolimy - od Piotra (V Niedziela) po Zacheusza (XXXI Niedziela) - uświadamiają sobie, że potrzebują przebaczenia i wielkiego miłosierdzia Bożego. Motyw miłosierdzia Bożego występuje w ciągu całego roku w szeregu opowieści charakterystycznych dla Ewangelii Łukaszowej: o jawnogrzesznicy (XI Niedziela), o miłosiernym Samarytaninie (XV Niedziela), o zaginionej owcy i synu marnotrawnym (XXIV Niedziela), o dobrym łotrze (XXXIV Niedziela). Pojawiają się także ostrzeżenia dla tych, którzy nie okazują miłosierdzia: przekleństwa i błogosławieństwa (VI Niedziela), historia bogatego głupca (XVIII Niedziela) oraz przypowieść o bogaczu i Łazarzu (XXVI Niedziela). Ewangelia Łukasza, pisana dla pogan, podkreśla, że miłosierdzie Boga sięga poza Jego naród wybrany i obejmuje tych, którzy pozostawali wykluczeni. Wątek ten przewija się przez te niedziele i niesie dla nas ostrzeżenie, kiedy zbiera

poważne niesprawiedliwości i grzechy, które on, według ich błędnej opinii, popełnił. Takie zachowania są niesłuszne, nieodpowiedzialne i zmierzają jedynie ku wyrządzeniu poważnych szkód wiernym, którzy nie będąc w stanie skontrolować osobiście tego rodzaju stwierdzeń, pozostaną nimi zmieszani i zgorszeni”. „Trudny temat przebaczenia. Rozmowa z o. Peterem Gumplem SJ", Zeszyty Formacji Duchowej 14 (2000): 24.

${ }^{31}$ Henryk Sławiński, „Znaczenie, geneza i struktura Dyrektorium homiletycznego”, Polonia Sacra 3 (2015): 168. 
my się na celebrowanie Eucharystii: otrzymaliśmy obfitość miłosierdzia Chrystusa i bez żadnych ograniczeń powinniśmy się nim dzielić z innymi (DH 145).

Dyrektorium wskazuje możliwość odwołania się do zagadnień związanych z przebaczeniem w homiliach podczas następujących niedziel roku liturgicznego: 7 niedziela zwykła roku A (modlitwa a wybaczanie nieprzyjaciołom - KKK 2842-2845); 10 niedziela zwykła roku A (Jezus wzywa grzeszników i udziela im przebaczenia - KKK 545, 589); 24 niedziela zwykła roku A („Przebacz nam nasze winy” - KKK 2838-2845); 7 niedziela zwykła roku B (Chrystus przebacza grzechy - KKK 987, 1441, 1741); 7 niedziela zwykła roku C (wybaczanie nieprzyjaciołom - KKK 1825, 1935, 1968, 2303, 2647, 2842-2845); 11 niedziela zwykła roku C (tylko Bóg wybacza grzechy - KKK 1441-1442:); oraz 4 niedziela wielkiego postu roku C (syn marnotrawny - KKK 1439, 1465, 1481, 1700, 2839; Bóg przebacza grzechy i przywraca grzesznika do wspólnoty - KKK 1441, 1443; drzwi przebaczenia są otwarte dla wszystkich skruszonych - KKK 982).

\section{Zakończenie}

Katechizm Kościoła Katolickiego poucza, że „czytanie Pisma świętego, Liturgia Godzin, modlitwa «Ojcze nasz», każdy szczery akt kultu lub pobożności ożywia w nas ducha nawrócenia i pokuty oraz przyczynia się do przebaczenia grzechów" (KKK 1437). Jednym z centralnych tematów przepowiadania homilijnego jest konieczność nawrócenia, które przejawia się również w postawie przebaczenia drugiemu człowiekowi. Homilia, czerpiąc z Pisma świętego oraz liturgii, będąc integralną częścią eucharystii, pomaga $\mathrm{w}$ porozumieniu się $\mathrm{z}$ drugim człowiekiem oraz zachęca do uwiarygodnienia swojej wiary przez postawę przebaczenia ${ }^{32}$. Przepowiadanie homilijne ma zatem ważne zadanie w systematycznym wychowywaniu do przebaczenia.

\section{Preparation for Forgiveness in Homilies (Summary)}

One of the basic criteria of authenticity of being a Christian is ability to forgive. One constantly needs to be brought up to this attitude. One of the missions of the

${ }^{32}$ Narecki, „Wartość przebaczenia”, 48; Jan Przybyłowski, „Wychowanie chrześcijańskie - pełny rozwój osoby ludzkiej”, Warszawskie Studia Pastoralne 2 (2005): 85. 
Church is to bring up her members. The real upbringing should comprise a full formation of a person and relate to the ultimate aim of his/her life as well as a common good of a community. The basic educational tasks of the Church are related to accomplishment of its redemptive functions: preaching the word of God, worshipping God and pursuing love of neighbours based on healthy love of oneself. One of the most important educational means, especially with respect to religious upbringing, possessed by the Church, is homiletic preaching. Among many issues, a homily takes up a problem of forgiveness. The aim of this paper is to present a special role of a homily in preparing for forgiveness. Consecutive points present the issues of a homilist as a pedagogue, a pedagogic role of a homily and the central issue - a homily of forgiveness. The final part of the paper presents suggestions of the newly published Homiletic Directory concerning the issue of preaching on forgiveness. A homily, with its sources in the Bible and the liturgy, being an integral part of the Eucharist, helps to communicate with another person and encourages its listeners to authenticate their faith by the attitude of forgiveness.

Key words: homily; forgiveness; upbringing; preaching; homilist.

\section{Wychowanie do przebaczenia w homiliach (Streszczenie)}

Jednym z podstawowych kryteriów autentyczności bycia chrześcijaninem jest umiejętność przebaczania. Do takiej postawy trzeba ciągle wychowywać. Jedną z misji Kościoła jest wychowywanie swoich członków. Prawdziwe wychowanie powinno obejmować pełną formację człowieka i odnosić się zarówno do ostatecznego celu życia człowieka, jak i dobra wspólnego społeczności. Podstawowe zadania wychowawcze Kościoła związane są z realizacją jego funkcji zbawczych: głoszenia Słowa Bożego, oddawania czci Bogu i realizowania miłości bliźniego, opierając się na zdrowej miłości samego siebie. Jednym z najważniejszych środków wychowawczych, zwłaszcza w zakresie wychowania religijnego, które są w dyspozycji Kościoła, jest przepowiadanie homilijne. Homilia wśród wielu innych podejmuje również zagadnienie przebaczenia. Celem niniejszego opracowania jest przedstawienie szczególnej roli homilii w wychowaniu do przebaczenia. W kolejnych punktach omówione są kwestie homilisty jako wychowawcy, wychowawczej roli homilii oraz zagadnienie centralne - homilii o przebaczeniu. W końcowej części opracowania przedstawione są sugestie nowowydanego Dyrektorium homiletycznego dotyczące zagadnienia przepowiadania na temat przebaczenia. Homilia, czerpiąc z Pisma świętego oraz liturgii, będąc integralną częścią eucharystii, pomaga w porozumie- 
niu się z drugim człowiekiem oraz zachęca do uwiarygodnienia swojej wiary przez postawę przebaczenia.

Słowa kluczowe: homilia; przebaczenie; wychowanie; przepowiadanie; homilista.

\section{Bibliografia}

Broński, Włodzimierz. „Homilia”. W: Leksykon teologii pastoralnej, red. Ryszard Kamiński, Wiesław Przygoda, Marek Fijałkowski, 288-291. Lublin: Towarzystwo Naukowe Katolickiego Uniwersytetu Lubelskiego Jana Pawła II, 2006.

Dyk, Stanisław. „Orędzie homilijne w okresie zwykłym w ciągu roku cyklu B”. Roczniki Liturgiczno-Homiletyczne 1 (2010): 17-39.

Franciszek. „O przebaczaniu: codziennie mamy do tego okazję”. http://www.opoka. org.pl/aktualnosci/news.php?id=58404\&s=opoka (dostęp: 28.12 .2015$)$.

Franciszek. Bulla ustanawiająca nadzwyczajny Jubileusz Miłosierdzia Misericordiae vultus (11.04.2015).

II Polski Synod Plenarny. Poznań-Warszawa: Wydawnictwo Pallottinum, 1991.

Jan Paweł II. „Wychowanie młodego pokolenia zadaniem wszystkich. Do uczestników europejskiego sympozjum na temat: «Wyzwania edukacji» (3 VII 2004)". L'Osservatore Romano 11 (2004): 22.

Kongregacja ds. Duchowieństwa. Kapłan głosiciel słowa, szafarz sakramentów i przewodnik wspólnoty $w$ drodze do trzeciego tysiąclecia chrześcijaństwa. Tarnów: Wydawnictwo Diecezji Tarnowskiej Biblos, 1999.

Kręcidło, Janusz. „Jakiego przebaczenia uczy nas Jezus?”. Ateneum Kapłańskie 156, 1 (2011), 25-34.

Lewek, Antoni. Współczesna odnowa kaznodziejstwa. Z najnowszych dziejów ruchu homiletycznego. Warszawa: Akademia Teologii Katolickiej, 1980.

Gosek, Marian. „Tworzywo homiletyczne”. W: Praktyka przepowiadania słowa Bożego. Materiały do nauczania w zakładach teologicznych, red. Leszek Kuc, t. 2, 283-397. Warszawa: Akademia Teologii Katolickiej, 1973.

Narecki, Zbigniew. ,Wartość przebaczenia i pojednania w pryzmacie współczesności”. Pedagogia Ojcostwa 1 (2015): 39-54.

Przybyłowski, Jan. „Deklaracja o wychowaniu chrześcijańskim Gravissimum educationis: wskazówki pastoralne dla funkcji wychowawczej Kościoła”. Warszawskie Studia Pastoralne 5 (2007): 37-54.

Przybyłowski, Jan. „Wychowanie chrześcijańskie - pełny rozwój osoby ludzkiej”. Warszawskie Studia Pastoralne 2 (2005): 71-97. 
Przyczyna, Wiesław. „Kaznodzieja jako herold”. W: Stuga Stowa, Wiesław Przyczyna, 51-63. Kraków: Wydawnictwo „Poligrafia Salezjańska”, 1997.

Reiterer, Friedrich Vinzenz. „Odpuszczenie grzechów/Przebaczenie”. W: Nowy leksykon biblijny, red. Franz Kogler, Renate Egger-Wenzel, Michael Ernst, 543. Kielce: Wydawnictwo „Jedność”, 2011.

Siwek, Gerard. „Przepowiadanie słowa Bożego”. W: Teologia pastoralna, t. 2, red. Ryszard Kamiński, 131-179. Lublin: Wydawnictwo Atla 2, 2002.

Sławiński, Henryk. „Wychowawcze znaczenie homilii ślubnej”. Teologia i Moralność 12 (2012): 103-119.

Sławiński, Henryk. „Znaczenie, geneza i struktura Dyrektorium homiletycznego”. Polonia Sacra 3 (2015): 155-176.

Sobór Watykański II. „Deklaracja o wychowaniu chrześcijańskim Gravissimum educationis". W: Sobór Watykański II, Konstytucje, dekrety, deklaracje, 313-324. Poznań: Pallottinum, 1967.

Szewczyk, Leszek. „Zagadnienia moralne w wypowiedzi kaznodziejskiej”. Ślaskie Studia Historyczno-Teologiczne 2 (2004): 48-57.

Szewczyk, Leszek. Recepcja liturgicznego wymiaru homilii. Studium homiletyczne na podstawie badań kaznodziejstwa kapłanów Archidiecezji Katowickiej w latach 1972-1999. Katowice: Wydawnictwo „Księgarnia św. Jacka”, 2003.

Tarnowski, Janusz. „Kaznodzieja jako wychowawca”. W: Stuga Stowa, red. Wiesław Przyczyna, 153-164. Kraków: Wydawnictwo „Poligrafia Salezjańska”, 1997. „Trudny temat przebaczenia. Rozmowa z o. Peterem Gumplem SJ”. Zeszyty Formacji Duchowej 14 (2000): 19-25.

Urbański, Stanisław. „Przebaczenie źródłem uzdrowienia i przemiany życia”. Zeszyty Formacji Duchowej 14 (2000): 48-54.

Wons, Krzysztof. „Miłość Słowa i złość grzechu”. Zeszyty Formacji Duchowej 14 (2000): 108-117.

Zaborowski, Marek. „Zadania nauczycielskie Kościoła w Polsce wobec współczesnych wyzwań rodziny". Pedagogika Katolicka 8 (2011): 84-99. 
